University of Nebraska - Lincoln

DigitalCommons@University of Nebraska - Lincoln

Nutrition and Health Sciences -- Faculty

Publications

Nutrition and Health Sciences, Department of

$4-2020$

\title{
Rural-Urban Differences in Roles and Support for Community Health Workers in the Midwest
}

Kate E. Trout

Virginia Chaidez

Angela L. Palmer-Wackerly

Follow this and additional works at: https://digitalcommons.unl.edu/nutritionfacpub

Part of the Communication Commons, Medicine and Health Commons, Medicine and Health Sciences Commons, and the Rural Sociology Commons

This Article is brought to you for free and open access by the Nutrition and Health Sciences, Department of at DigitalCommons@University of Nebraska - Lincoln. It has been accepted for inclusion in Nutrition and Health Sciences -- Faculty Publications by an authorized administrator of DigitalCommons@University of Nebraska Lincoln. 


\title{
Rural-Urban Differences in Roles and Support for Community Health Workers in the Midwest
}

\author{
Kate E. Trout, ${ }^{1}$ Virginia Chaidez, ${ }^{2}$ and Angela L. Palmer-Wackerly ${ }^{3}$ \\ 1. Department of Natural Sciences, Peru State College, Peru, Nebraska, USA \\ 2. Nutrition and Health Sciences, University of Nebraska-Lincoln, Lincoln, Nebraska, USA \\ 3. Communication Studies, University of Nebraska-Lincoln, Lincoln, Nebraska, USA \\ Corresponding author - Virginia Chaidez, PhD, RD, Nutrition and Health Sciences, University of Nebraska- \\ Lincoln, 110 Ruth Leverton Hall, Lincoln, NE 68583, email vchaidez2@unl.edu
}

\begin{abstract}
The Patient Protection and Affordable Care Act supports the integration of community health workers (CHWs) into the health care workforce, but little is known about integration and current roles of CHWs among employers in community settings. This analysis of 97 employers described the roles of CHWs in Nebraska and found significant differences between CHWs practicing in rural and urban areas in organization types employing CHWs, funding sources, and minority populations served. The findings suggest that the utility of CHWs is widely recognized among employers, but deliberate support will be needed to better define the roles of CHWs to meet the needs of the increasingly diverse demographic.
\end{abstract}

Keywords: community health workers, prevention, rurality, workforce development

The Patient Protection and Affordable Care Act (PPACA) has supported the integration of community health workers (CHWs) into the health care workforce by putting an emphasis on community-based care in efforts to reach underserved communities. The PPACA aims to improve access to health care services for all, especially low-income, underserved, uninsured, minority, health disparity, and rural populations. CHWs have been shown to provide cost savings, increase access to care, and reduce unnecessary health service utilization. ${ }^{1-4}$ There are an estimated 56,130 CHWs in the United States, ${ }^{5}$ although these are conservative estimates considering they do not account for unpaid or volunteer CHWs. 
However, little is known about the integration and current roles of CHWs among employers in health care and community settings, where the majority of studies have highly focused on achieving health outcomes, disease management, and cost-effectiveness rather than the activities of CHWs. ${ }^{6-9}$ Integrating CHWs will be key as the health care system moves toward new health care models that focus on delivering cost-effective and timely care, such as the Patient-Centered Medical Home or the Integrated Primary Care and Community Support (I-PaCS).

CHWs' roles are expansive and can be integrated into a variety of different facets within the health care system as trusted community leaders, including facilitating data collection, program enrollment, community outreach, care delivery, disease management, care coordination, assisters/navigators for insurance programs, and provision of culturally and linguistically appropriate, patient- and family-centered care. ${ }^{10}$ To better inform policy and program efforts in reaching the populations emphasized in the PPACA, more rigorous methods for monitoring are needed to help identify the populations CHWs are serving and the activities they regularly perform. State-level surveillance creates opportunities that affect the training and deployment of health professionals, plan for educational programs, shape regulatory policies, identify shortage areas, forecast employment needs, create justification for funding, and evaluate the impact that policy decisions have on CHW workforce. ${ }^{11}$ Accurate information about a state's current workforce is necessary to evaluate existing efforts of incorporating CHWs into the continuum of care and to plan for future employer needs in these efforts.

CHWs are critically important in rural areas with limited health care services by acting as liaisons between providers and consumers and providing culturally competent care. Rural health is recognized as one of the 14 health disparities by Healthy People 2020, and ensuring access to health care for rural communities has been a persistent challenge across the United States. When compared with urban populations, rural populations face geographic isolation, high rates of health risk behaviors, lower socioeconomic status, higher rates of chronic disease, and overall poor health, coupled with lower rates of health insurance and employer-provided health care coverage, and have been plagued by chronic health care provider shortages..$^{12}$ These challenges contribute to higher incidences of disease and disability, increased mortality rates, lower life expectancies, and higher rates of pain and suffering than their urban counterparts. ${ }^{12}$ Nebraska is a largely rural state with 87 of 93 counties either entirely or partly rural. ${ }^{13}$ About $35 \%$ of the population lives in rural areas, making Nebraska a good model to study rurality and how to decrease the health disparity. There have been no studies that have reported the differences in roles of CHWs working in urban and rural settings nor whether any difference exists within the regular daily activities. The objective of this study was to determine the roles of CHWs in Nebraska, including activities regularly performed and populations served. Furthermore, an exploratory analysis was conducted to determine whether any differences exist between $\mathrm{CHWs}$ practicing in rural and urban areas. 


\section{Methods}

This study uses secondary data collected as part of the Community Health Worker Employer Survey and contains questions related to workplace environment, priorities, and perceived needs and support. Workplace environment and priority questions were adapted from the Public Health Workforce Interests and Needs Survey (PH WINS). ${ }^{14}$ Survey questions related to employers' perceived need and support for CHWs were adapted from Douglas County Health Department CHW Survey in Nebraska.

In March 2017, the survey was sent to 500 employers identified to be potential employers as well as potential future employers of CHWs in rural and urban settings, including local health departments, health care organizations, churches, schools, and University of Nebraska-Lincoln (UNL's) Cooperative Extension. Details on purposive sampling are described elsewhere; briefly, the survey was sent via postal mail to individuals identified as an appropriate person who either managed or supervised CHWs or would be in a position to supervise a CHW through website evaluations and contacting community partners via telephone and e-mail. ${ }^{15}$ Follow-up postcard reminders were sent after 1 week, and replacement surveys were mailed to nonrespondents 3 weeks after the initial survey mailing in efforts to increase the response rate.

There were 240 employers that returned the survey, resulting in a response rate of $48.4 \%$. The study included those employers that identified employing CHWs in urban and rural areas, which could include volunteer, current employees, or recently employed CHWs. Those respondents that did not identify the rurality of which their $\mathrm{CHWs}^{\prime}$ practice were excluded from the study. This study explores the differences between urban and rural CHWs' activities, populations served, employer characteristics, and support for CHWs. Of the employers that responded to the survey, 97 identified having CHWs working in rural and urban areas. Organizations that identified employing CHWs who practiced in urban and suburban areas were classified as urban, and those organizations that employed CHWs who only practiced in rural areas were classified as rural. The question provided in the survey was as follows: "Please indicate below which of the following settings CHWs in your organization work in regularly." Organization type was reported in the survey. Health care organizations in clinical settings include hospitals $(n=1)$, Federally Qualified Health Centers (FQHCs) $(n=1)$, and health clinics $(n=1)$. Data summary statistics and bivariate analyses were performed using Stata/IC v.14.1. Frequency distributions were analyzed. The $\chi^{2}$ test was used to assess the associations between the categorical variables and rurality. Fisher's exact test was used in situations where cell counts were fewer than 5 in 1 or more cells.

\section{Results}

Table 1 describes employers of CHWs and the populations the CHWs target in rural and urban areas. The majority of organizations that currently employ CHWs were from local health departments (32\%), followed by schools (22\%), community-based organizations $(20 \%)$, congregations/faith-based organizations (9\%), University of Nebraska Extension $(5 \%)$, and clinical settings (3\%). There were significantly more schools that employ CHWs 
in rural settings $(31 \%)$ than located in urban settings $(13 \%)(P=.03)$. Furthermore, there were significantly more churches/faith-based organizations that employed CHWs practicing in urban settings $(15 \%)$ than in rural settings $(2 \%)(P=.02)$.

Table 1. Descriptive Statistics of Employers of Community Health Workers among Urban and Rural Areas in Nebraska

\begin{tabular}{|c|c|c|c|c|}
\hline Variable & $\begin{array}{c}\text { Total }(N=97) \\
n(\%)\end{array}$ & $\begin{array}{c}\text { Rural }(n=45), \\
n(\%)\end{array}$ & $\begin{array}{c}\text { Urban }(n=52) \\
n(\%)\end{array}$ & $P$ \\
\hline \multicolumn{5}{|l|}{ Organization type } \\
\hline Local health department & $31(32)$ & $17(38)$ & $14(27)$ & .25 \\
\hline Community based-organization & $19(20)$ & $9(20)$ & $10(19)$ & .92 \\
\hline School & $21(22)$ & $14(31)$ & $7(13)$ & $.03^{\mathrm{a}}$ \\
\hline $\begin{array}{l}\text { Congregation and faith-based } \\
\text { organizations }\end{array}$ & $9(9)$ & $1(2)$ & $8(15)$ & $.02^{\mathrm{a}, \mathrm{b}}$ \\
\hline University of Nebraska Extension & $5(5)$ & $0(0)$ & $5(10)$ & $.05^{\mathrm{b}}$ \\
\hline Clinical setting & $3(3)$ & $2(4)$ & $1(2)$ & $.59 \mathrm{~b}$ \\
\hline Other & $9(9)$ & $2(4)$ & $7(13)$ & $.12^{\mathrm{b}}$ \\
\hline \multicolumn{5}{|l|}{ Funding } \\
\hline Government & $74(76)$ & $34(76)$ & $40(77)$ & .93 \\
\hline General operating budget & $66(68)$ & $30(67)$ & $36(69)$ & .97 \\
\hline Private & $31(32)$ & $10(22)$ & $21(40)$ & $.04^{\mathrm{a}}$ \\
\hline Fee for service & $27(28)$ & $12(27)$ & $15(29)$ & .81 \\
\hline Other & $4(4)$ & $3(7)$ & $1(2)$ & $.28^{\mathrm{b}}$ \\
\hline \multicolumn{5}{|l|}{ Targeted ethnic groups } \\
\hline White & $84(87)$ & $40(89)$ & $44(85)$ & $.08^{\mathrm{b}}$ \\
\hline Hispanic or Latino & $71(73)$ & $31(69)$ & $40(77)$ & .80 \\
\hline Black & $54(56)$ & $16(36)$ & $38(73)$ & $.001^{\mathrm{a}}$ \\
\hline Native American & $44(45)$ & $21(47)$ & $23(44)$ & .88 \\
\hline Asian & $35(36)$ & $12(27)$ & $23(44)$ & .11 \\
\hline Pacific Islander & $15(15)$ & $8(18)$ & $7(13)$ & .48 \\
\hline \multicolumn{5}{|l|}{ Targeted populations } \\
\hline Women & $87(90)$ & $39(87)$ & $48(92)$ & .17 \\
\hline Men & $84(87)$ & $37(82)$ & $47(90)$ & .22 \\
\hline Minorities & $81(84)$ & $36(80)$ & $45(87)$ & 1.00 \\
\hline Family & $72(74)$ & $34(76)$ & $38(73)$ & .96 \\
\hline Elderly & $58(60)$ & $26(58)$ & $32(62)$ & .54 \\
\hline Pregnant women and new parents & $55(57)$ & $24(53)$ & $31(60)$ & .65 \\
\hline LGBT & $43(44)$ & $15(33)$ & $28(54)$ & .08 \\
\hline \multicolumn{5}{|l|}{ Targeted age groups } \\
\hline Adults & $79(81)$ & $36(80)$ & $43(83)$ & .57 \\
\hline Seniors & $60(62)$ & $27(60)$ & $33(63)$ & .68 \\
\hline Infants/young children & $51(53)$ & $26(58)$ & $25(48)$ & .28 \\
\hline Adolescents & $49(51)$ & $27(60)$ & $22(42)$ & $.03^{\mathrm{a}}$ \\
\hline
\end{tabular}

Abbreviation: LGBT = lesbian, gay, bisexual, and transgender aStatistically significant: $P<.05$

'Fisher's exact test was used; insufficient cell count in 1 or more cells

The major funding source for CHWs was government funds (76\%), followed by general operating budget (68\%), private (32\%), fee-for-service (28\%), and other $(4 \%)$. Other funding 
sources identified by employers were grants $(n=2)$, state health hub funds $(n=1)$, insurance $(n=1)$, school state and federal funds $(n=2)$, and nonprofit $(n=1)$. Employers with CHWs practicing in urban settings more frequently were funded from private funds $(40 \%)$ than their rural counterparts $(22 \%)(P=.04)$.

When looking at populations served by $\mathrm{CHWs}$, there were no significant differences in working with gender or minority groups between those employers with $\mathrm{CHWs}$ practicing in urban and rural settings. However, there were significant differences between specific ethnic/racial minority groups. Employers with CHWs practicing in urban areas worked more frequently with black populations $(73 \%)$ than their rural counterparts $(36 \%)(P=.001)$. Employers with CHWs practicing in rural areas more often worked with adolescents $(60 \%)$ than employers with CHWs practicing in urban settings $(42 \%)(P=.03)$.

Table 2 summarizes the workplace environment for supporting $\mathrm{CHWs}$ regarding educational and networking support. Almost all employers reported encouraging continuing education (93\%), allowing use of working hours to participate in training (93\%), paying travel and/or registration fees for training (94\%), and providing onsite training $(89 \%)$. About three-fourths (74\%) of employers include education and training objectives in performance reviews. More than half $(57 \%)$ of employers require continuing education for CHWs. About two-thirds of employers have positions responsible for training (66\%) and provide recognition for achievement to CHWs (68\%). About $41 \%$ of employers reported providing education at the beginning of employment to $\mathrm{CHWs}$ within their agencies, and about a quarter $(24 \%)$ reported offering education outside of their agencies.

\begin{tabular}{|c|c|c|c|c|}
\hline Variable & $\begin{array}{c}\text { Total }(N=97) \\
n(\%)\end{array}$ & $\begin{array}{c}\text { Rural }(n=45), \\
n(\%)\end{array}$ & $\begin{array}{c}\text { Urban }(n=52) \\
n(\%)\end{array}$ & $P$ \\
\hline \multicolumn{5}{|l|}{ Education } \\
\hline Require continuing education & $55(57)$ & $29(64)$ & $26(50)$ & .11 \\
\hline Encourage continuing education & $90(93)$ & $45(100)$ & $45(87)$ & .11 \\
\hline $\begin{array}{l}\text { Include education and training objectives } \\
\text { in performance reviews }\end{array}$ & $72(74)$ & $36(80)$ & $36(69)$ & .42 \\
\hline $\begin{array}{l}\text { Allow use of working hours to participate } \\
\text { in training }\end{array}$ & $90(93)$ & $43(96)$ & $47(90)$ & 1.00 \\
\hline Pay travel/registration fees for training & $91(94)$ & $44(98)$ & $47(90)$ & 1.00 \\
\hline Provide on-site training & $86(89)$ & $40(89)$ & $46(88)$ & .62 \\
\hline Positions responsible for training & $64(66)$ & $30(67)$ & $34(65)$ & .98 \\
\hline Recognition for achievement & $66(68)$ & $29(64)$ & $37(71)$ & .23 \\
\hline \multicolumn{5}{|l|}{ Networking opportunities with other CHWs } \\
\hline $\begin{array}{l}\text { Offer group training session with other } \\
\text { organizations }\end{array}$ & $51(53)$ & $22(49)$ & $29(56)$ & .49 \\
\hline Open discussions with other agencies & $52(54)$ & $22(49)$ & $30(58)$ & .08 \\
\hline $\begin{array}{l}\text { Public Health Association of Nebraska } \\
\text { CHW section meeting }\end{array}$ & $23(24)$ & $15(33)$ & $8(15)$ & $.03^{\mathrm{a}}$ \\
\hline Regular meetings with local area CHWs & $30(31)$ & $13(29)$ & $17(33)$ & .43 \\
\hline Conferences & $55(57)$ & $26(58)$ & $29(56)$ & .43 \\
\hline Need to hire more CHWs & $65(67)$ & $33(73)$ & $32(62)$ & .21 \\
\hline
\end{tabular}

Abbreviation: $\mathrm{CHW}=$ community health worker

aStatistically significant: $P<.05$ 
As illustrated in Figure 1, employers with CHWs practicing in urban areas more frequently provide education to CHWs upon employment within their agency (50\%) than their rural counterparts $(31 \%)(P=.04)$. In contrast, employers with CHWs practicing in rural areas more frequently provide education upon employment of $\mathrm{CHWs}$ outside of their agency than their urban counterparts but at relatively lower frequencies $(31 \%$ and $17 \%$, respectively) $(P=.04)$.

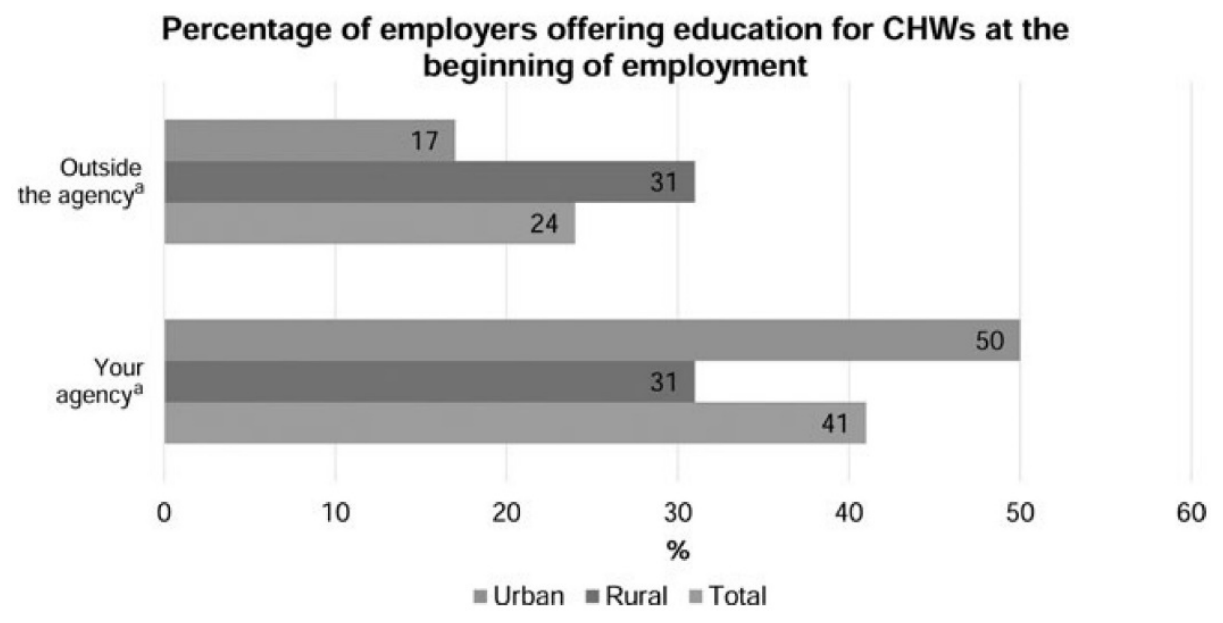

Figure 1. Education opportunities at the beginning of employment for CHWs among urban and rural areas in Nebraska. aStatistically significant: $P<.05$; values do not add up to $100 \%$ because some employers did not offer training or did not know. CHW indicates community health worker.

Employers less frequently reported activities to support networking opportunities for CHWs than educational support within their workplace environment. Conferences (57\%) were the most frequently reported networking opportunity by employers. Half of employers reported having open discussions with other agencies (54\%) and offering group training sessions with other organizations (53\%). Less than one-third of employers reported having regular meetings with local area CHWs (31\%) and attending the Public Health Association of Nebraska (PHAN) CHW section meeting (24\%). However, employers with CHWs practicing in rural areas more frequently attended the PHAN CHW section meeting (33\%) than their urban counterparts $(15 \%)(P=.03)$. When asked about the need for CHWs at their organization, two-thirds $(67 \%)$ of employers reported that they need to hire more CHWs.

The majority of the employers identified that CHWs regularly performed activities as collaborating with other agencies (89\%), educating and informing (88\%), making referrals $(82 \%)$, and performing data collection, entry, and/or analysis (81\%). Relatively few employers reported that $\mathrm{CHWs}$ regularly engage in fundraising and/or grant writing (29\%) and/or case finding and recruitment (28\%). Other regularly performed activities are reported in Figure 2. There were no significant differences in activities regularly performed 
by CHWs between those organizations that employ CHWs practicing in urban and rural settings (data not shown).

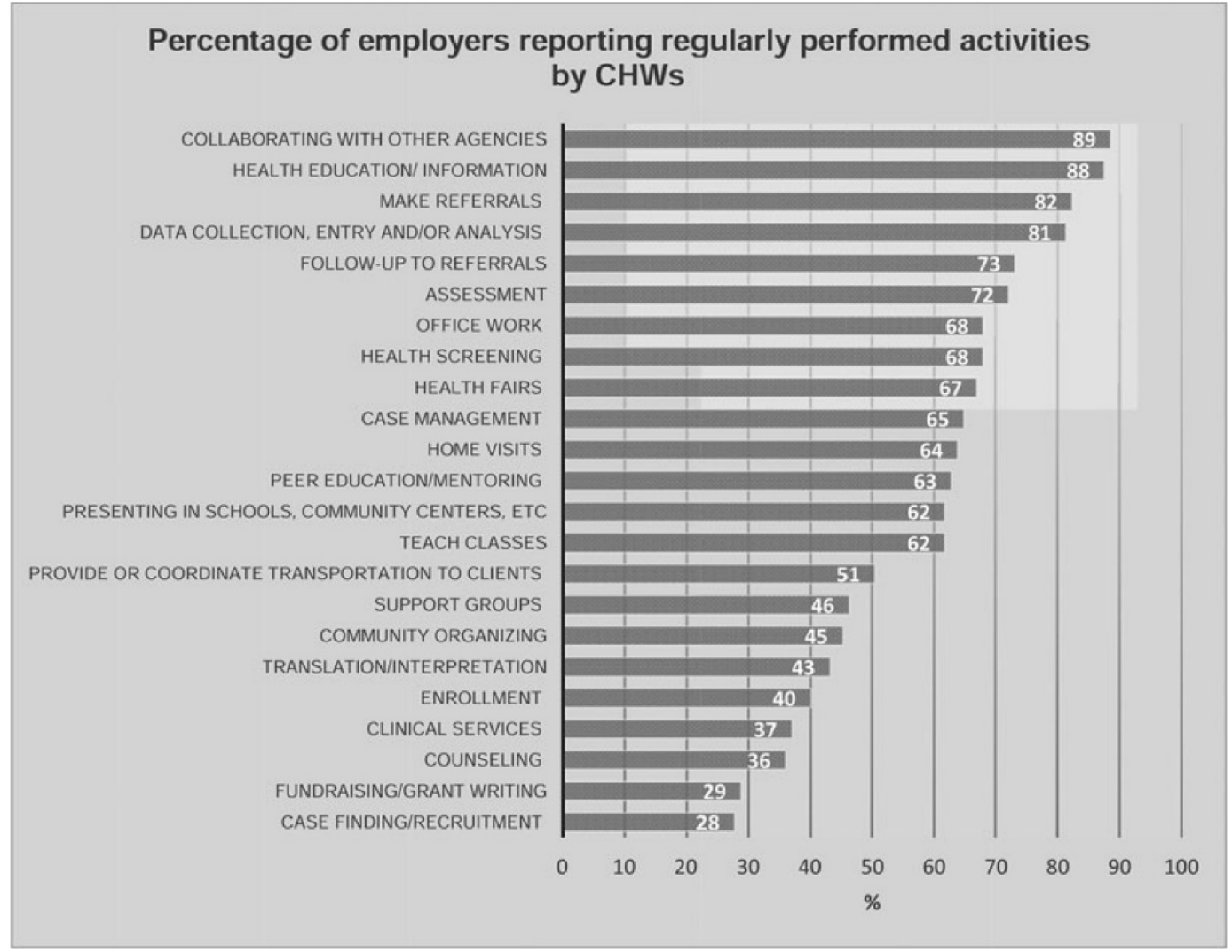

Figure 2. Regularly performed activities for community health workers among urban and rural areas in Nebraska. ${ }^{a} P<.05$.

\section{Discussion}

The PPACA aims to improve access to health care services for low-income, underserved, uninsured, minority, health disparity, and rural populations. However, there may not be enough support or definition in the roles of CHWs to provide a stable workforce structure to employ CHWs in community settings. Currently, Nebraska has adopted a set of core competencies and provides training resources and policy recommendations for $\mathrm{CHWs}$, all of which serve to guide development of a growing workforce. ${ }^{16}$ There is still considerable flexibility in allowing employers or organizations to train $\mathrm{CHWs}$ as they see fit since there are a variety of needs CHWs can help fill. Similarly, there is variation across states in what has been implemented and adopted, while still others have proposed newer frameworks for advancing the profession. ${ }^{17-19}$ Two thirds (67\%) of the study population reported the need to hire more $\mathrm{CHWs}$, suggesting that the utility of $\mathrm{CHWs}$ is widely recognized among employers in Nebraska. Government funds (76\%) and general operating budget $(68 \%)$ 
were the major sources of funding for CHWs. However, employers with CHWs practicing in urban settings were more frequently funded by private funds $(40 \%)$ than their rural counterparts $(22 \%)(P=.04)$. A multistate study found that $\mathrm{CHWs}^{\prime}$ activities and roles are not well understood by employers, making it a challenge to identify funding sources for CHW positions. ${ }^{20}$ Consequently, the majority of funding for CHWs is often "soft funding" that is short-term (such as grants), which creates positions for CHWs that are often unstable and temporary, affecting their ability to remain in communities. ${ }^{20}$ Identifying stable funding sources will be important for the sustainability of CHW positions within organizations in community settings. Collaborative and networking opportunities with urban counterparts may help rural employers identify potential private funding sources for CHWs. Employers of urban practicing CHWs should be encouraged to collaborate with rural CHWs, especially at the PHAN CHW section meeting. CHWs practicing in rural areas more frequently attended the meeting (33\% vs. $15 \%)$. Conferences $(57 \%)$, interorganizational training sessions (53\%), and discussions (54\%) may have good reach to CHWs practicing in rural and urban areas and should be used to disseminate information, implement targeted programs, gather feedback, and stimulate networking opportunities. Future studies should identify other barriers in hiring more $\mathrm{CHWs}$ and incorporating them into their current activities.

This study examined the frequency at which minority groups are targeted by CHWs. Eighty-four percent of employers reported that their CHWs target minority groups, and less than half of employers reported targeting Native American (45\%), Asian (36\%), Pacific Islander (15\%), and LGBT (lesbian, gay, bisexual, and transgender) (44\%) groups. The majority of counties in Nebraska are experiencing a rising minority population, while the white/majority population is undergoing a decline. ${ }^{21}$ In fact, from 2000 to 2010, the population minority share of total population growth was $95.4 \%$ in Nebraska, with Hispanic/ Latino populations experiencing the fastest population growth. ${ }^{21}$ Less than three-fourths (73\%) of employers reported that their CHWs target Hispanic populations. Forecasting the needs of populations while anticipating the change in health care professionals, for both licensed and nonlicensed providers, will be important to inform policy makers, programs, and educational initiatives. Rural areas in Nebraska face severe health care workforce challenges into the future, where nearly one-fifth of physicians are older than 60 years, 18 of 93 counties do not have a pharmacist, more than $60 \%$ of counties are designated shortage areas for family physicians, and all but 2 counties in the state have been designated to be shortage areas for at least one type of primary care specialty. ${ }^{22} \mathrm{CHWs}$ have the ability to deliver culturally competent care and will be important to help meet the needs of the increasingly diverse demographic in Nebraska coupled with the long-standing provider shortages across Nebraska. Emphasis on serving these specific minority populations in Nebraska may need reinforcement by health care and community workforce initiatives to meet the changing population demographics in Nebraska.

Rural populations and health care providers face unique challenges because their populations are older, are sicker, have higher rates of poverty, are more likely to be uninsured, have less education, and are largely covered by federally designated physician shortage areas. ${ }^{23,24} \mathrm{~A}$ recent study demonstrated that there is a negative correlation between the percentage of minority residence in rural areas with gaining new Rural Health Clinics (RHCs) 
and FQHCs. ${ }^{25}$ RHCs and FQHCs help provide coverage in rural areas experiencing provider shortages, but the study showed that rural areas with higher minority residence were less likely to gain either clinic type to increase access to care. When examining the differences between rurality and populations targeted, employers with CHWs practicing in urban areas worked more frequently with black populations (73\%) than their rural counterparts $(36 \%)(P=.001)$. In Nebraska, the majority of black populations live in urban areas. It is projected by the US Census Bureau that the black/African American population will increase by $33 \%$ during the period of $2005-2025 .{ }^{26}$ With this projected increase, it will be important that deliberate attention be given in reaching minority populations before this persistent rural disparity continues to emerge across the spectrum of health care providers. Furthermore, research suggests that these rural racial/ethnic minority populations have been largely understudied and overlooked, resulting in generally more severe disparities in health and in health care access than their urban counterparts. ${ }^{27}$ Rural health disparity research should incorporate the distribution of specific minority groups in rural areas. More education and resources are needed for employers of CHWs to target minority populations in efforts to avoid the reoccurrence of this inequity in accessing health care services.

Employers with $\mathrm{CHWs}$ practicing in urban areas more frequently provided education upon employment within their agency (50\% vs. $31 \%$ ) than those in rural areas, and employers with $\mathrm{CHWs}$ practicing in rural areas more frequently provided education outside of their agency ( $31 \%$ and $17 \%$, respectively) than those in urban areas. This result is not surprising because rural areas have smaller populations to serve that limits their gains in revenue, have a more limited workforce due to the difficulty in recruitment and retention of health care professionals, and have less adequate capacity and resources for health planning due to financial and human-capital constraints. ${ }^{28-30}$ As a result, these constraints and limitations in resources may impact rural employers' ability to offer education within their agencies, where they have to outsource their employee training more often than urban employers. In addition, the study found that there were significantly more churches/faithbased organizations that employed CHWs practicing in urban settings $(15 \%)$ than in rural settings $(2 \%)(P=.02)$. Besides supporting religious activities, churches and faith-based organizations are trusted institutions where black populations seek support. ${ }^{26,27}$ Research has found that churches and faith-based organizations have been valuable venues to promote health programs among black populations. ${ }^{31,32}$ In Nebraska, black populations disproportionately live in urban areas as compared with rural areas. This may be coupled with the fact that rural areas have limited access to resources and smaller congregations, making it more difficult for rural congregations and faith-based organizations to support the structure to involve CHWs. However, employers with $\mathrm{CHWs}$ practicing in rural areas more often work with adolescents $(60 \%)$ than employers with CHWs practicing in urban settings $(42 \%)(P=.03)$. This result may be observed because there were significantly more schools that employ $\mathrm{CHWs}$ in rural settings $(31 \%)$ than those located in urban settings $(13 \%)$ in the study populations $(P=.03)$. Urban schools and organizations that work with youth may be important organizations to incorporate the use of CHWs for health topics such as mental health and suicide prevention, ${ }^{33}$ asthma control, ${ }^{34}$ preventing eating and 
body image problems, ${ }^{35}$ promoting health behaviors, ${ }^{36}$ immunizations, health education, family planning, and other emerging community-specific adolescent health topics.

\section{Directions for future research}

The majority of the employers identified that CHWs regularly collaborate with other agencies $(89 \%)$, educate and inform (88\%), make referrals $(82 \%)$, and engage in data collection, entry, and/or analysis (81\%). Relatively few employers reported CHWs regularly engage in fundraising and/or grant writing (29\%) and/or case finding and recruitment $(28 \%)$. There were no significant differences between activities regularly performed by CHWs in urban versus rural communities although the study at hand is subject to response bias where employers were asked to complete questions related to CHWs activities. The responses may represent generalizations about CHW functions within the organization but not the specific actions of individual CHWs. Future studies should gather detailed information directly from CHWs regarding the frequency and time distribution of activities performed. This study helps provide preliminary information of activities regularly performed, populations served, and support for $\mathrm{CHW}$ s from the employer perspective in $\mathrm{Ne}-$ braska.

Future studies should collect more comprehensive information to capture CHWs who work in multiple locations and split their time between locations. For example, some organizations that employ CHWs may be located in an urban area but CHWs may practice part of their time in rural locations. Future studies should include more comprehensive variables to assess service area of CHWs and rurality, such as county, census track, and zip code. Because of the limitations of the variables collected by the survey, the rurality of employers was classified as having urban practicing CHWs if they reported having any CHWs practicing in urban or suburban settings. Of the employers reporting employing urban practicing $\mathrm{CHWs}, 22$ reported also having $\mathrm{CHWs}$ practicing in rural settings. A sensitivity analysis concluded that all but one result held true after excluding the responses to employers that had CHWs practicing in both urban and rural settings $(n=22)$. There was no longer a significant difference between the frequency of providing education upon employment within their agency $(P=.16)$ or outside of their agency $(P=.16)$. The result had marginal significance $(P=.047)$, and this difference may have resulted in the loss of power in the sample size. Organizations located in urban areas typically have more resources and human capacity to offer educational opportunities within their organization. A larger sample size could provide more power to determine the impact of rurality on ability to offer education within organizations for CHWs.

For the purposes of this study, the sample included the responses of only those employers that had reported the involvement of CHWs in their organization. The information provided by this study can help support the development of a comprehensive sampling frame of employers of CHWs in Nebraska. There is a large body of literature demonstrating that $\mathrm{CHWs}$ are extremely beneficial when incorporated into clinical settings by providing cost savings, reducing waste, improving patient self-management skills, improving clinical outcomes, and providing higher patient and physician satisfaction of overall care. ${ }^{1,37,38}$ However, little is known about the types of community settings employing CHWs in 
Nebraska. The strength of this study is to provide information from employers of CHWs in community settings, especially since CHWs focus on upstream prevention efforts. Statelevel policy and support should work toward outlining more defined roles of CHWs and provide a framework for a broader integration of CHWs in clinical settings in Nebraska. Finally, because of the small sample size and limited information in the data set, the study was not able to control for other explanatory variables that may influence $\mathrm{CHW}$ activities and support, such as organization size and resources, patient characteristics, ownership, and affiliation. This exploratory study has identified potential factors that are influenced by rurality, such as funding, targeted populations, and networking and educational opportunities available for CHWs within organizations.

\section{Conclusion}

CHWs will be important actors to help meet the needs of the increasingly diverse demographic in Nebraska coupled with the long-standing provider shortages across rural areas of Nebraska. The utility of CHWs is widely recognized among employers in Nebraska. Government funds and general operating budget are the major sources of funding for $\mathrm{CHWs}$, but it may not be enough to provide sustainable positions for $\mathrm{CHWs}$ within diverse community organizations. Identifying and securing stable funding sources will be important for CHWs to successfully incorporate into the continuum of care, especially in rural areas. CHWs and other nonlicensed providers should be incorporated into state level health professionals' tracking and enumeration efforts to provide more comprehensive data. To direct workforce development efforts, health care stakeholders should work toward better defining the roles of CHWs in rural and urban settings. Doing so will be important for $\mathrm{CHWs}$ to adopt their expanded role in serving as an integral part of the health care system, as recognized by the PPACA. Deliberate support should be given to better define the roles of CHWs in Nebraska with an emphasis on serving minority populations.

Acknowledgments - This project is based on research that was partially supported by the Nebraska Agricultural Experiment Station with funding from the Hatch Act (accession no. 1011764) through the USDA National Institute of Food and Agriculture and the Layman Fund at the University of Nebraska-Lincoln. The authors acknowledge the Bureau of Sociological Research (BOSR) for its assistance in managing data collection and data entry; graduate students Ashley Mulcahy and Miteshri Prajapati for their assistance in compiling mailing lists; and various community partners including Ronnette Sailors at Catholic Health Initiatives Health; Josie Rodriguez, Danielle Wing, Kathy Karsting, and Margarita Allen at Nebraska Department of Health \& Human Services; Patty Falcone at Douglas County Health Department; Jessie Perez and Denise Zweiner at Buffalo County Community Partners; and Pat Lopez at Public Health Association of Nebraska.

The authors declare no conflicts of interest. 


\section{References}

1. Enard KR, Ganelin DM. Reducing preventable emergency department utilization and costs by using community health workers as patient navigators. J Healthc Manag. 2013;58(6):412-427.

2. Fedder DO, Chang RJ, Curry S, Nichols G. The effectiveness of a community health worker outreach program on healthcare utilization of west Baltimore City Medicaid patients with diabetes, with or without hypertension. Ethn Dis. 2003;13(1):22-27.

3. The Institute for Clinical and Economic Review. Community Health Workers: A Review of Program Evolution, Evidence on Effectiveness and Value, and Status of Workforce Development in New England. Boston, MA: The New England Comparative Effectiveness Public Advisory Council; 2013.

4. Swider SM. Outcome effectiveness of community health workers: an integrative literature review. Public Health Nurs. 2012;19(1):11-20.

5. Bureau of Labor Statistics. Occupational employment and wages, May 2018: 21-1094 community health workers. https://www.bls.gov/oes/current/oes211094.htm. Published 2019. Accessed October 1, 2019.

6. Arrossi S, Thouyaret L, Herrero R, et al. Effect of self collection of HPV DNA offered by community health workers at home visits on uptake of screening for cervical cancer (the EMA study): a population-based cluster-randomised trial. Lancet Glob Health. 2015;3(2):e85-e94.

7. Costa EF, Guerra PH, dos Santos TI, Florindo AA. Systematic review of physical activity promotion by community health workers. Prev Med. 2015;81:114-121.

8. Kim K, Choi JS, Choi E, et al. Effects of community-based health worker interventions to improve chronic disease management and care among vulnerable populations: a systematic review. Am J Public Health. 2016;106(4):e3-e28.

9. Palmas W, March D, Darakjy S, et al. Community health worker interventions to improve glycemic control in people with diabetes: a systematic review and meta-analysis. J Gen Intern Med. 2015;30(7):1004-1012.

10. Islam N, Nadkarni SK, Zahn D, Skillman M, Kwon SC, Trinh-Shevrin C. Integrating community health workers within Patient Protection and Affordable Care Act implementation. J Public Health Manag Pract. 2015;21(1):42-50.

11. Gaul K, Fraher E. State-Level Health Workforce Data Collection, Analysis, and Dissemination: An Introduction. Rensselaer, NY: The Health Workforce Technical Assistance Center; 2015. www .healthworkforceta.org/wpcontent/uploads/2015/03/TAtoStatesResourceBrief.pdf. Accessed June 15, 2018.

12. Rural Health Information Hub. Rural health disparities. https://www.ruralhealthinfo.org/topics/ rural-healthdisparities. Published 2017. Accessed June 13, 2018.

13. Federal Office of Rural Health Policy. List of Rural Counties and Designated Eligible Census Tracts in Metropolitan Counties. Rockville, MD: Health Resources and Services Administration; 2016. https://www.hrsa.gov/sites/default/files/ruralhealth/resources/forhpeligibleareas.pdf. Accessed June 20, 2018.

14. Leider JP, Bharthapudi K, Pineau V, Liu L, Harper E. The methods behind PH WINS. J Public Health Manag Pract. 2015;21(suppl 6):S28-S35. doi:10.1097/ PHH.0000000000000285.

15. Chaidez V, Palmer-Wackerly AL, Trout KE. Community Health Worker Employer Survey: perspectives on CHW workforce development in the Midwest. J Community Health. 2018;43(6):11451154. doi:10.1007/s10900-018-0533-x. 
16. Lopez P. Development of Nebraska's Community Health Worker Workforce. Lincoln, NE: Public Health Association of Nebraska-Community Health Worker Section; 2015. http://publichealthne .org/wp-content/uploads/2015/04/CHWPolicyPaper3-30-15editsPat.pdf. Accessed October 1, 2019.

17. Allen CG, Brownstein N, Cole M, Hirsch G, Williamson S, Rosenthal EL. Building a framework for community health worker skills proficiency assessment to support ongoing professional development. J Ambul Care Manage. 2018;41(4):298-307.

18. Covert H, Sherman M, Miner K, Lichtveld M. Core competencies and a workforce framework for community health workers: a model for advancing the profession. Am J Public Health. 2019; 109(2):320-327.

19. Dorhauer K, Morton T, Quijada P, St. John J. Community Health Workers: Recommendations for Bridging Healthcare Gaps in Rural America (Policy Brief).Washington, DC: National Rural Health Resource Center; 2017:1-22.

20. Alvisurez J, Clopper B, Felix C, et al. Funding community health workers: best practices and the way forward. http://www.healthreform.ct.gov/ohri/lib/ohri/sim/care_delivery_work_group/funding _chw_best_practices.pdf. Published 2013. Accessed August 19, 2018.

21. Drozd D. Comparing Nebraska Population Change by Race and Ethnicity. NEXUS: Making the Connection. Omaha, NE: University of Nebraska at Omaha Center for Public Affairs Research (CPAR); 2017. No. 2017-1. https://www.unomaha.edu/college-of-public-affairs-andcommunity-service/centerfor-public-affairs-research/documents/comparing-population-change-by-raceethnicity.pdf. Accessed August 19, 2018.

22. Wilson FA, Wehbi NK, Larson J, Mosalpuria K, Chen E, Deras M. The Status of the Healthcare Workforce in the State of Nebraska. Omaha, NE. UNMC Center for Health Policy; 2018.

23. National Rural Health Association. What's different about rural health care? http://www.rural healthweb.org/go/left/about-rural-health/what-s-different-about-ruralhealth-care. Accessed August 20, 2018.

24. Newkirk V, Damico A. The Affordable Care Act and Insurance Coverage in Rural Areas: Issue Brief. San Francisco, CA: The Henry J. Kaiser Family Foundation Headquarters; 2014. https://kaiserfamilyfoundation.files.wordpress.com/2014/05/8597-the-affordable-careact-and-insurancecoverage-in-rural-areas1.pdf. Accessed August 20, 2018.

25. Ko M, Cummings JR, Ponce NA. Changes in the supply of US rural health centers, 2000-2011: implications for rural minority communities. J Rural Health. 2016;32(3):245-253.

26. Population Division, US Census Bureau. Projected State Populations, by Sex, Race, and Hispanic: 1995-2025. Washington, DC: Population Division, US Census Bureau; 1996.

27. Probst JC, Moore CG, Glover SH, Samuels ME. Person and place: the compounding effects of race/ethnicity and rurality on health. Am J Public Health. 2004;94(10):1695-1703.

28. Kaufman BG, Thomas SR, Randolph RK, et al. The rising rate of rural hospital closures. J Rural Health. 2016; 32(1):35-43.

29. Rabinowitz HK, Diamond JJ, Markham FW, Paynter NP. Critical factors for designing programs to increase the supply and retention of rural primary care physicians. JAMA. 2001;286(9):10411048.

30. Anderson A. The Impact of the Affordable Care Act on the Health Care Workforce. Washington, DC: The Heritage Foundation; 2014.

31. Bryant K, Moore T, Willis N, Hadden K. Development of a faith-based stress management intervention in a rural African American Community. Prog Community Health Partnersh. 2015; 9(3):423. 
32. Hartwig JF. Faith-based community health interventions: incorporating cultural ecology, the social ecological framework, and gender analysis. In: Kim DK, Singhal A, Kreps GL, eds. Health Communication: Strategies for developing global health programs. New York, NY: Peter Lang Publishing; 2014:244-261.

33. Nebraska Department of Health and Human Services (NE DHHS), Division of Public Health. State Health Assessment: Nebraska. Lincoln, NE: Division of Public Health Office of Community Health and Performance Management; 2016.

34. Margellos-Anast H, Gutierrez MA, Whitman S. Improving asthma management among AfricanAmerican children via a community health worker model: findings from a Chicago-based pilot intervention. J Asthma. 2012;49(4):380-389.

35. O'Dea J, Maloney D. Preventing eating and body image problems in children and adolescents using the health promoting schools framework. J Sch Health. 2000;70(1):18-21.

36. Berkey CS, Rockett HR, Field AE, et al. Activity, dietary intake, and weight changes in a longitudinal study of preadolescent and adolescent boys and girls. Pediatrics. 2000;105(4):E56.

37. Otero-Sabogal R, Arretz D, Siebold S, et al. Physician community health worker partnering to support diabetes self-management in primary care. Qual Prim Care. 2010;18(6):363-372.

38. Roby DH, Pourat N, Pirritano MJ, et al. Impact of patient centered medical home assignment on emergency room visits among uninsured patients in a county health system. Med Care Res Rev. 2010;67(4):412-430. 